\title{
Reality in Ruins Before and After the Catastrophe: The Case of Two Contemporary Polish Novels
}

\author{
Katarzyna Trzeciak \\ Jagiellonian University
}

\begin{abstract}
This article explores the problematic status of reality before and after Holocaust. Taking two different Polish novels as examples, the author deals with the metaphor of ruins, remains, and ashes to define the ontological status of the world in two texts. In the first text, Piotr Szewc's annihilation brings the positive vision of ruin as a kind of fragile and finite being which needs love and care. In the second text, Piotr Pazinski's Pensjonat shows that ruin is only a negative aspect of reality which is illegible and empty. The main concern of the text is to oppose those two visions and make a conclusion about the dialectic of the ruin.
\end{abstract}

Keywords: ruins, Holocaust, memory, ethic, dialectic

\begin{abstract}
This mere word, spaced without space, affirming beneath all affirmation, Impossible to deny, too weak to be killed, too docile to be contained, Not saying anything, only speaking, speaking without living,

Without voice, in a voice lower than any voice. (Maurice Blanchot, L'Attente l'oubli)
\end{abstract}

In his essay on the relationship between writing and disaster, Maurice Blanchot says:

When the disaster comes upon us, it does not come. The disaster is its imminence, but since the future, as we conceive of it in the order of lived time, belongs to the disaster, the disaster is always already withdrawn or dissuaded; there's no future for the disaster, just as there's no time or space for its accomplishment. (Blanchot 1986, 1-2)

For Blanchot, the disaster is a gift that "takes care of everything" (Blanchot 1986, 3). The last sentence has a special importance for my analysis concerning the status of reality before and after Holocaust. I chose two Polish novels, written long after the events of the Holocaust, struggling with the subject of death, which, though absent explicitly, organizes all fictional realities.

\section{Toward the Love of Ruins}

First discussed text, Piotr Szewc's Annihilation is a kind of imaginative journey back to the prewar reality of provincial Polish-Jewish town. Szewc creates a world of details presenting a single day in July 1934.

What is surprising about Annihilation is that, with the exception of the title and some indirect foreshadowings, none of this destruction is found in its pages. The text itself, its surface, maintains a tone of tenderness and unhurried observation, concerned not with the future but only with its present ambition to

Katarzyna Trzeciak, Ph. D., Faculty of Polish Studies, Jagiellonian University, Poland; main research fields: Literary, Anthropology, and Literary Theory. Email: katarzyna.trzeciak@uj.edu.pl. 
"chronicle the events in the Book of the Day," of which everyone and everything in the town is a part (Riker 2013).

The reality of a small town seems coherent and stable: every citizen of the town lives his ordinary life, does his routine activities, and "the weather changes, but nothing unexpected happens" (Shallcross 1994, 472). But Annihilation is more than a simple idyllic view of prewar social life. At the very beginning of the history, there is a peculiar inclusion saying that all those small facts and observations (about the present activity of a few characters) are irrelevant from the perspective of the most important events of the future. Moreover, those facts are lost in the future and no memory or no photography will save them. So even now they are only like a burnt paper or like a dust scattered randomly in time. All this idyllic reality from the beginning is doomed to non-existence.

How can we read those collections of images and know that they are already destroyed? We know that this world of Polish provincial town is more than utopian vision, but on the other hand, it is not an image of the Holocaust catastrophe. We also know that this world does not exist anymore in the time of narrator's presence. This world is beyond the metaphorical meaning of the fading utopia and at the same time it can't be treated as a literal testimony of the disaster. In Annihilation, there is something more that should be named and written. There is something "like a dust" or ashes which stays between presence and absence.

Eduardo Cadava called that kind of image with the enigmatic relation between death and survival, loss and life, destruction and preservation, and mourning and memory as an "image of ruin":

The image tells us that it is with loss and ruin that we have to live. Nevertheless, what makes the image an image is its capacity to bear the traces of what it cannot show, to go on, in the face of this loss and ruin, to suggest and gesture toward its potential for speaking. In other words, the fact of the image's existence, and here I refer only to an image worthy of the name "image," to an image that would remain faithful to the ruinous silences that make it what it isruins the ruin about which all images speak - or at least seek to speak. (Cadava 2001,36)

The image that "bears the traces of what it cannot show" is the image of catastrophe in Szewc's book. The narrator of the text is the character who knows more about the world he presents. Both the reader and the narrator know the future of the small town. And from such perspective, this image is an image of ruined reality. Such meaning of ruins is far from being conventional. Ruin here is not seen as an effect of certain catastrophe or as a kind of product of the stream of time (Hetzler 1982, 105). In Annihilation, reality in ruins is presenting both anticipation and effect of the Shoah.

The ideal and coherent life in Polish town could be interpreted as nostalgic for a lost entirety of the world that was broken by the catastrophe. But in this text, such nostalgia is presented as impossible. There is no coherence when narrator says that everything in this reality is like "burnt paper." Other fragments from the text only emphasize this statement: "What we now see up close, on the photography is not visible or difficult to guess" (Szewc 2003, 9) and once more: "Soon our tracks disappear. Let us stop a moment when they are still visible. Order of the future will deny them" (Szewc 2003, 20). At the moment of being taken the photo by some passer-by on the street, the image immediately turns into illegible ruin. In fact, the image "is" a ruin, as Cadava (following Walter Benjamin) writes that an image, as a "historical index" is an object in which "the Then and the Now come together into a constellation like a flash of lightning" (Cadava 2001, 38). The relation of the Then and the Now is not temporal in nature but imagistic. But this "Now," in which we could make the image legible, is composed of all the images that are synchronic with it, like the present is never simply "Now," 
because it is never separable from "Then."

This is why the historical index of an image always claims the image for another time, for another historical moment (itself plural, and composed of several other moments), and for something other than linear, chronometric time (which would be, for Benjamin, "purely temporal" and "continuous"). This is also why Benjamin's understanding of the image's historical index cannot be understood as either indexical or referential: it can never index or refer to a single historical moment or event (Benjamin 1999, 39).

In Annihilation, images of the "Then" interfere with the images of the "Now" and therefore they both become illegible. The image from the future (narrator's presence) interrupts the presence of the characters; they think they are at the beginning of dying although they still don't know about this. The reality lasts between life and death as a compilation of fragments from the world that doesn't exist anymore. The reality created by the narrator is not a kind of conservation, it is rather a world that is thrall of the impossible real and according to Blanchot, this is the most fundamental relation between writing and the catastrophe, as he indicates: "Write in order not simply to destroy, in order not simply to conserve, in order not to transmit; write in the thrall of the impossible real and that share of disaster, wherein every reality, safe and sound, sinks"(Blanchot 1986, 38).

Writing about ruined images can be a reconstruction of the passed reality, but in Annihilation, this reconstruction is not the spatio-temporal entirety of the broken image. This is rather an act of collecting traces, or better-"cinders" according to Derrida. Derrida states: "Cinder is the best paradigm that I call the trace—something that erases itself totally and radically, while presenting itself" (Derrida 1987, 177).

Cinder is at once the best name for the absence of a truly proper name for what holds all beings and entities in presence, and by the same token just another name that cannot begin to assess its distance or proximity to the final proper name (or names) of the truth of Being, whose very existence remains undecidable (Lukacher 1991, 1).

Cinder resists being a metaphor "which brings things to presence and sustains them there" (Lukacher 1991, 2). It also resists being a proper name of the truth of Being. Cinder rather names a "relation" to the possibility of the truth. Cinder opens the space in which the truth might come and a space for possibilities of the metaphoric and the literal without being reducible to either of them. This is exactly the case of Szewc's "ashes" at the beginning of my analysis. The "remains of a burnt paper," as the narrator named all the facts and characters from the story, is not a randomly given appellation. "Remains of a burnt paper," cinders, are the very specific names associated with the fire. "In the warmth of a cinder one can feel the effects of the fire even if the fire itself remains inaccessible, outside cognition though not without leaving a trace" (Lukacher 1991, 3). In Szewc's novel, the flames of Holocaust are inaccessible for both the characters and readers. There are only traces of them interrupting the peaceful story of the small town's daily life. From the reader's perspective, the fire has already consumed the access to the reality presented in the novel, as Derrida says. But the left cinder remains allows the relation between the present world and the indestructible truth of passed reality smolders within the ashes. And it is possible only because "cinders name both the extreme fragility and the uncanny tenacity of this relation" (Lukacher 1991, 3).

The status of the fictional reality in Annihilation has also one more meaning-it demands certain ethical responsibility from the viewer of this image. The viewer of the ruin image experiences has to respect:

its infinite inability to become anything other than a ruin, or restore oneself to a ruin. That is, it is an act that collapses again and again, infinitely, in front of its collapsing or ruining again and again. In other words, it is a respect for the ruin's self-deconstructing of itself by one's self-deconstructing of oneself, the iteration of one's traces in front of the other tracing 
itself into the infinitely other. This is not a mutual relation, and it is an impossible relation, but it remains what happens in an ethical call to respect the ruination that occurs already in a text or drawing (or a person) composed and composing itself in traces. (Duffy, 2007)

These relations between viewer and ruined image is the relation of love. In Derridian philosophy of the ruin:

One cannot love a monument, a work of architecture, an institution as such except in an experience itself precarious in its fragility: it has not always been there, it will not always be there, it is finite. And for this very reason one loves it as mortal, through its birth and its death, through one's own birth and death [à travers sa naissance et sa mort], through the ghost or the silhouette of its ruin, one's own ruin [sa ruine]-which it already is, therefore, or already prefigures. How can one love otherwise than in this finitude? Where else would the right to love, even the love of law, come from [d'ou viendrait autrement le droit d'aimer, voire l'amour du droit]? (Derrida 2002, 278)

In Annihilation, Piotr Szewc presents similar ethic of loving ruined image. The first sentence of the whole history is: "We are on Listopadowa, the second street crossing Lwowska" (Szewc 2003, 5). This "we" involves the reader in a high level of intimacy with the written reality. A little farther there is the sentence already quoted: "Let us stop a moment when they are still visible." The intimacy of "we" implies participation, and the participation implies ethical responsibility. By saying "let us" the narrator insists "on the need of this action" (Riker 2013); we must seize the moment when traces are still present. This also suggests that those traces disappear in the future, so the people who left them are only temporary beings; fragile and finite. And it is because of the finite existence of the image that we have to take care of the traces. Finally, it is because of the fragility of those beings that the whole story is possible as a story of the reality which has already passed and at the same time is still present. The love of ruins is the only possible way to get an access into past, present and future reality. Even if (perhaps even more) that reality is always already just a cinder.

\section{Against the Dispersal of Reality}

The second analysed text, Piotr Pazinski's Pensjonat, strongly emphasizes the problem of post-Holocaust memory. The hero of the novel visits Jewish resident hotel where he stayed as a child with his grandmother. In the past, this house was full of life, its residents were arguing, dancing, and playing cards.

Crowds of walkers were spending summer evenings huddling on the sidewalk and Warsaw burghers were walking back and forth, carelessly as if the world was not marching to perdition. People loved affairs and begeted children. Owners were counting takings, and guests ordered room for next year (Pazinski 2009, 8).

Today, Jewish resident hotel is also full but it is full of spectres which last in its walls. When the narrator comes to this place, he notes at the beginning that everything there is as before, as if the process of disintegration of matter slowed down there. In fact, the whole building retained its splendour but it seems to be asleep. The hero meets the old manager of the hotel and its several other old residents who survived the Shoah. The rest of people presented in the novel are the spirits of the dead who live on the same ontological level as present residents. The narrator begins to walk through the abandoned rooms and see the things which remained after the people who no longer exist. Surrounded by these objects, the hero feels that he is at home. But it's impossible to bring back the previous reality of this place. All the traces of the past found by the hero are now illegible and unknowable. He found old letters but the writing is blurred and he can't manage to read them. The situation reminds one of Blanchotian words: "Reading is anguish and this is because any text [...] is empty-at bottom it doesn't exist; you have to cross an abyss, and if you do not jump, you don't comprehend" (Blanchot $1986,10)$. The texts that come from the reality before the Holocaust are now empty because their sense is now 
impossible to catch and understand. But at the same time, this sense is the existence condition of the hero because he knows that his present life is determined by this illegible past. He even says that this past is the origin of his sense of life on the island, some of inadequacy, and mismatch. And pessimistic realization that everything passes is rooted in just that time. That's why he wants after all to reveal the past actively recalling the people who were alive when he was a child.

Active recalling means above all "creating" the past reality in order to avoid present dispersion of the hero's subjectivity. The narrator has mixed the real and non-existent characters, writes to the deceased his own completely invented stories and gradually makes it impossible to distinguish between the ontological positions of the characters of the story. Walter Benjamin who interprets the figure of collector and the concept of literary text as a collection notes: "Perhaps the most deeply hidden motive of the person who collects can be described in this way: he takes up the struggle against dispersion”(Benjamin 1999, 211). The narrator in Pazinski's novel struggles against dispersion of his present identity by constructing fictional stories of his old friends from the hotel. But the activity of constructing has a paradoxical structure. Every time the narrator tells the story of some character, this character becomes increasingly removed from its prototype. The individuality of each character fades away and disappears in the noise of voices of all imaginary and real characters:

One could hear everywhere uproar and noise and endless ongoing discussions over cookies and coffee. As if nothing else has already had to do and just wanted by its idle tales, re-shape anew this the best of all worlds. I almost can't hear their words and I can't distinguish the voices in the dark, pulled into one pulsating stream inside the head. As I can't remember all their names, I can't recognize the faces, which I almost can't see, and which sometimes seem to be only the outline of one face, a trace of one and the same mask. (Pazinski 2009, 81)

Whom this mask belongs to? I believe that the owner of this mask is the narrator himself. His present reality is inhabited by fragments of representations from his memory and at the same time this memory works as a screen on which imaginary stories are projected. This dual performance both makes memory the instance of ethical restoring life and at the same time kills any singularity.

The writer's present is inhabited then by the fragments of representations from his memory. This same memory stands between himself and a non-representationally mediated nature, yet the barrier that memory puts between the self and nature prevents the writer from living in an immediate relation with himself through the perception of a "Natural Object." Memory then is an abyss inhabited by representations which invade the writer's present, cut him off from nature, and separate him from himself (Donato 1978, 593-594).

When the narrator of Pensjonat asks about the possibility of reading the letters found, he wants to save all the dead characters from oblivion and he wants the impossible. But remembering is mediation, a barrier that brings something closer by moving it away. The final consequence of this process of annihilation is the emptiness of the remembering subject who is away from himself. Here, we may follow the considerations of Blanchot who notes that:

If it is the other who exposes me to "unity," causing me to believe in an irreplaceable singularity, for I feel I must not fail him; and at the same time he withdraws me from what would like make me unique: I am not indispensable; in me anyone at all is called by the other-anyone at all as the one who owes him aid. The un-unique, always substitute. [...] I owe everything, including the loss of myself. (Blanchot 1986, 13)

This is precisely the condition of Pazinski's hero. The others, residents of the hotel, those who are still living and the dead, determine the singularity of narrator and the idiom of his past. But at the same time, they 
deprive him of the singularity, when he fails to read the letters. The narrator owes everything, so he fills the space of hotel by creating the imaginary characters but then he becomes more and more distant from his origins. Finally, he says that every time he is trying to find his past in himself, he goes to the hollow void of his own subjectivity.

The present reality of Pazinski's hero is an effect of all those creations of the past. So instead of knowing the sources of his life, he invents them in order to avoid the confrontation with the emptiness of his own world. Active remembering which should be an act of exploring the past and completing the present reveals that the sources can be reached only through the act of invention. And only such invention masks the obscure truth that the reality before the Shoah is not accessible for contemporary reader and viewer. The present reality remains divided between the desire to invent the past and the knowledge that this invention only deepens the present void of reality.

\section{Conclusion}

Both the analysed texts are associated with the problematic relation between the reality and the catastrophe. The catastrophe, though not explicitly available, defines the whole possibility of existence. One may understand the metaphor of ruin connected with the catastrophe and appearing in the title of this essay as dual. In an affirmative sense, as is in Szewc's Annihilation, ruins allow one to explore reality which is destined to die. In this sense, the fragile and finite reality demands love and care. And at the same time, there is no other world except these ruins that one can love.

On the other hand, in Pazinski's Pensjonat, we can see the negative meaning of the ruins and remains emphasising their incompleteness. It arouses one's desire for completeness. And completeness can be reached only through inventing the past reality. The invented past can't be treated as a source of the present by the main hero of the novel who finally understands that dispersion is the only attainable condition of the reality.

\section{Works Cited}

Benjamin, Walter. The Arcades Project. Trans. Howard Eliand, and Kevin McLauglin. Cambridge: Harvard University Press, 1999.

Blanchot, Maurice. The Writing of the Disaster. Trans. Ann Smock. Lincoln: University of Nebraska Press, 1986.

Cadava, Eduardo. "Lapsus Imaginis": The Image in Ruins. Vol. 96. Massachusetts: The MIT Press, Spring, 2001.

Derrida, Jacques. Acts of Religion. Trans. Gil Anidjar. New York \& London: Routledge, 2002.

Derrida, Jacques. Cinders. trans. Ned Lukacher. Lincoln \& London: University of Nebraska Press, 1991.

Derrida, Jacques. "Research in Phenomenology." On Reading Heidegger: An Outline of Remarks to the Essex Colloquium. Vol. 17. 1987.

Donato, Eugenio. "The Ruins of Memory: Archeological Fragments and Textual Artifacts.” MLN. Vol. 93. No. 4. French Issue: Autobiography and the Problem of the Subject, 1978.

Duffy, Michael. Derrida, Ruins and Love. 2013. <http://mikejohnduff.blogspot.com/2007/12/derrida-ruins-and-love.html>

Lukacher, Ned. "Introduction: Mourning Becomes Telepathy." Cinders. Trans. Ned Lukacher. Lincoln \& London: University of Nebraska Press, 1991.

Pazinski, Piotr. Pensjonat. Warsaw: Wydawnictwo Nisza, 2009.

Schallcross, Bozena. “The Polish Review.” Annihilation. Vol. 39. No. 4. 1994.

Szewc, Piotr, Zagłada. Cracow: Wydawnictwo Literackie, 2003.

Riker, Martin. "Reading Piotr Szewc's 'Annihilation'." < http://www.dalkeyarchive.com/reading-piotr-szewcs-annihilation/> 2013. 